\title{
Quantitative analysis of the beef cattle industry in the state of Pará, Brazil
}

\section{Análise quantitativa do mercado de bovinos de corte no estado do Pará, Brasil}

\author{
Marcos Antônio Souza dos Santos ${ }^{1 *}$; José de Brito Lourenço Júnior²; Antônio \\ Cordeiro de Santana ${ }^{1}$; Alfredo Kingo Oyama Homma ${ }^{3}$; Cyntia Meireles Martins ${ }^{1}$; \\ Stefano Juliano Tavares de Andrade ${ }^{2}$; André Guimarães Maciel e Silva ${ }^{2}$
}

\begin{abstract}
The state of Pará has the fifth largest cattle herd in Brazil at 20.3 million heads, and beef cattle breeding accounts for $44.32 \%$ of the agricultural production value. Using a recursive econometric model estimated by the generalized method of moments, we evaluated the effects of variables that define the supply and demand of slaughtered beef cattle from 1990 to 2015. The results showed that supply and demand were inelastic to prices. Increases in rural salary and calf prices negatively affected supply, and the response to rural credit applications occurred with a four-year lag due to the biological and technological characteristics of production systems. Deforestation tended to increase the supply of cattle and slaughterhouses appropriated the largest share of the economic surplus generated. There were productivity gains since the early 1990s, with the yield of slaughtered animals was $230.55 \mathrm{~kg}$ for cattle and $182.25 \mathrm{~kg}$ for cows, while currently, it is 276 and $202.5 \mathrm{~kg}$, respectively. The creation of the Agriculture and Livestock Defense Agency of the State of Pará had a positive effect on the supply of cattle and the expansion of agroindustry structure, contributing to the supply of large markets with higher quality beef.
\end{abstract}

Key words: Econometric methods. Demand. Supply. Beef cattle breeding. Amazon.

\section{Resumo}

O estado do Pará possui o quinto maior rebanho bovino do Brasil, 20,3 milhões de cabeças, e a pecuária de corte responde por $44,32 \%$ do valor da produção agropecuária. Avaliaram-se os efeitos das variáveis que definem a oferta e a demanda de bovinos de corte abatidos no período de 1990 a 2015, por meio de um modelo econométrico recursivo estimado pelo Método Generalizado dos Momentos. A oferta e a demanda são inelásticas a preços. Aumentos no salário rural e no preço do bezerro impactam negativamente sobre a oferta e a resposta às aplicações de crédito rural ocorre com defasagem de quatro anos em função das características biológicas e tecnológicas dos sistemas de produção. $\mathrm{O}$ desmatamento tende a aumentar a oferta de bovinos e os frigoríficos se apropriam da maior parcela do excedente econômico gerado. Ocorreram ganhos de produtividade desde o início da década de 1990, pois o rendimento de carcaça dos animais abatidos era de 15,37 arrobas para bois e 12,15 arrobas para vacas e, atualmente, são de 18,4 e 13,5 arrobas, respectivamente. A criação da Agência de Defesa

${ }_{1}$ Profs. Drs., Instituto Socioambiental e dos Recursos Hídricos, Universidade Federal Rural da Amazônia, ISARH-UFRA, Belém, PA, Brasil. E-mail: marcos.santos@ufra.edu.br, acsufra@gmail.com; cyntiamei@hotmail.com

2 Profs. Drs., Programa de Pós-Graduação em Ciência Animal, Instituto de Medicina Veterinária, Universidade Federal do Pará, IMV-UFPA, Castanhal, PA, Brasil. E-mail: joselourencojr@yahoo.com.br; stefano.andrade@gmail.com; andregms@gmail.com

${ }^{3}$ Pesquisador, Dr., Empresa Brasileira de Pesquisa Agropecuária, EMBRAPA Amazônia Oriental, Belém, PA, Brasil. E-mail: alfredo.homma@embrapa.br

* Author for correspondence 
Agropecuária do estado do Pará exerceu efeito positivo sobre a oferta de bovinos e a ampliação da estrutura agroindustrial, contribuindo para o abastecimento de mercados amplos com carne bovina de maior qualidade.

Palavras-chave: Métodos econométricos. Demanda. Oferta. Pecuária de corte. Amazônia.

\section{Introduction}

Breeding beef cattle is the most important activity in the rural economy of Pará, as it constitutes $40 \%$ of agricultural establishments, regardless of size (IBGE, 2016a). In 2015, its herds totaled 20.3 million heads, $9.42 \%$ of the national total, and the highest amount among the North Region states and fifth in the country (IBGE, 2016b). Pastures are the main form of land occupation, with 16 million hectares, of which $28 \%$ are in an advanced state of degradation (ALMEIDA et al., 2016; INPE, 2016a). In the same year, according to data from the Ministry of Agriculture, Livestock, and Supply, the beef cattle industry generated $44.32 \%$ of the income of Pará's agricultural sector (MAPA, 2016a).

Livestock farming in Pará has been growing rapidly since the 1970s. The most pronounced phase occurred between 1970 and 1990, driven by agricultural colonization policies, fiscal incentives, and infrastructure projects, which attracted large numbers to Pará. In the early 1970s, the state of Pará represented $1.5 \%$ of the national herd, in 1990 this share reached $4.2 \%$, corresponding to a growth rate of $10.6 \%$ per year, much higher than in the same period, which was $2.6 \%$ per year (IBGE, 2016b).

Between 1990 and 2015, the herd grew at a rate of $5.5 \%$ per year, well above that observed in the country at $1.7 \%$ per year, indicating continuing growth (IBGE, 2016b). However, this growth is now in a new context, with greater pressure on land, labor, and environmental regularization, institutional changes in financing and animal health policies, and the expansion of the production chain with the implementation of several slaughterhouses under federal, state, and municipal inspection. It also demonstrates new standards of consumer demand, especially in the international market, interested in the socioeconomic and environmental characteristics of production systems, meat quality, and added value to products, with significant implications for market relations of beef cattle breeding in the state of Pará and Amazon (BARBOSA et al., 2015; HOMMA, 2017). This has substantially increased the demand for animals for slaughter to serve local, national, and international markets.

In the state of Pará, the slaughter of cattle is concentrated in fridges and slaughterhouses currently numbering 55 establishments, 14 with the Federal Inspection System (SIF), 14 with the State Inspection System (SIE) and 27 under municipal inspection (IBGE, 2016c). In 2015, these establishments slaughtered a total of 2.7 million head of cattle, corresponding to a slaughter rate of $13.1 \%$, and representing $8.6 \%$ of the total cattle slaughtered in Brazil. Of this total, 55.1\% were oxen and $44.9 \%$ were cows. Fridges under federal inspection slaughter 581 heads of cattle per day on average, constituting $73.5 \%$ of slaughtering, and produce primarily for the national and international market. Fridges under state inspection slaughter 148 heads on average and meet the state demand, representing $18.8 \%$ of the slaughtering. Slaughterers under municipal inspection slaughter an average of 30 heads a day to meet the local demand, and account for only $7.4 \%$ of the slaughtering (IBGE, 2016c).

This article aims to estimate the parameters of an econometric model of the slaughtered beef cattle market in the state of Pará, covering the period 19902015 , evaluate the effects of the factors affecting the demand and supply of cattle, and estimate the elasticity coefficients. These results contribute to the understanding of economic relations between 
the agents that participate in the market and the effects of public policies on the production chain of beef cattle breeding.

\section{Material and Methods}

\section{Study area and data used}

The state of Pará, with an area of approximately 1.25 million $\mathrm{km}^{2}$, is the study area. It makes up $14.7 \%$ of Brazilian territory and has a population of 8.2 million, $4 \%$ of the national population. The cattle population is approximately 20.3 million head, representing $9.42 \%$ of the national herd and $43 \%$ of the Northern Region of Brazil (IBGE, 2016b).

We used time series that cover the period from 1990 to 2015 . We use this period to measure the effect of the deforestation variable, whose database is only available for this time horizon. This variable is fundamental in the analysis of the cattle market in the Amazon, and particularly, in the state of Pará. We use it to evaluate the effect of deforestation dynamics on the increase in supply of cattle, as we expect a positive correlation between these variables (RIVERO et al., 2009). However, the displacement of livestock supply occurs with time lag, as deforestation initially affects the timber market and these areas are only used for agricultural and livestock activities after a few years (SANTANA et al., 2011). The variables of live cattle price and per capita income by municipality and state became available annually in this period. Furthermore, from the 1990s, owing to the supply of credit from the Northern Constitutional Financing Fund (FNO), livestock farming presented higher performance (SANTANA, 2002, 2012; SANTOS et al., 2007). Thus, we specified the equations of supply and demand of cattle using the variables presented below.

The data of cattle herds and total cattle slaughtered under federal, state, and municipal inspection are from the Municipal Livestock
Research and the Quarterly Animal Abattoir Survey of the Brazilian Institute of Geography and Statistics (IBGE, 2016b,c). We obtained data on the rate of deforestation from the database of the Monitoring System for Deforestation of the Legal Amazon of the National Institute for Space Research (INPE, 2016b) and live cattle price from the State Secretariat for Agricultural Development and Fisheries of the state of Pará (SEDAP, 2016). The values of per capita income, rural salary, and prices of products related to the cattle market (calf, milk, chicken, and swine) are from the Institute of Applied Economic Research (IPEADATA, 2016). The values of rural credit applications in cattle are from the Statistical Yearbook of Rural Credit of the Central Bank of Brazil (BACEN, 2016). All monetary variables were corrected for December 2015, based on the General Price Index - Internal Availability (IGP-DI) of the Getúlio Vargas Foundation (FGV, 2016).

\section{Econometric model}

The pricing dynamics of the beef cattle market are determined by the interrelationship between the demand and supply of cattle slaughtered in the state of Pará. The proposed model refers to market relations at the producer level, where the slaughtering agroindustry fulfills demand through fridges and cattle slaughterhouses under federal, state, and municipal inspection, and supply by cattle ranchers.

The slaughter is concentrated in slaughterhouses under federal inspection (14 slaughterhouses), which constitute an oligopsony - a market structure with few large buyers. Of the total slaughtered animals, $73.8 \%$ belong to the same business group or are branches of large groups established in other states in the Amazon and Brazil, which generates strong interdependence between companies, as some of the fridges with SIF are in the state of Pará. Such a market structure allows for a greater possibility of exercising market power, which generates incentives for cartelization; therefore, the 
actions of one or more groups may influence the purchase price of cattle for slaughter (GOODWIN, 1994; SANTOS et al., 2007; BOECHAT; ALVES, 2014; MOITA; GOLANI, 2014).

The market is a perfect competition type on the supply side. Many producers, each offering a small quantity of a commodity (beef cattle for slaughter) in relation to the total size of the market, in a business environment where information on production technologies and prices are available to market participants, and there is no limitation on the entry of new producers. Cattle ranchers become price takers in such a market (NORWOOD; LUSK, 2008).

The econometric model is composed of the following economic relations: supply and demand and an identity equation. We used the total number of cattle slaughtered under federal, state, and municipal inspection systems from 1990 to 2015 as the variable to measure demand and supply. The structural model is specified below, and all variables except dummy variables and trend were specified in the logarithmic form. Thus, the coefficients can be directly interpreted as elasticities.

$$
\begin{aligned}
& Q O B_{t}=a_{0}+a_{1} P B_{t-4}+a_{2} S R_{t}+a_{3} C R_{t-4}+a_{4} P B Z_{t}+ \\
& a_{5} T D M_{t-2}+a_{6} V D_{1 t}+a_{7} T+e_{1 t}(1) \\
& Q D B_{t}=b_{0}+b_{1} P B_{t}+b_{2} R_{t}+b_{3} V D_{1 t}+e_{2 t}(2) \\
& Q D B_{t}=Q O B_{t}=Q B_{t}(3)
\end{aligned}
$$

Wherein, endogenous variables:

$Q D B_{t}$ and $Q O B_{t}=$ natural logarithm of the

- number of heads of cattle slaughtered in the state of Pará from 1990 to 2015.

$P F_{t}=$ natural logarithm of the real price of live

- cattle in the state of Pará, in R\$/arroba, from 1990 to 2015.

Exogenous and instrumental variables:
$R_{t}=$ natural logarithm of real per capita GDP as

- a proxy for income in the state of Pará, in $\mathrm{R} \$ /$ inhab., from 1990 to 2015.

$S R_{t}=$ natural logarithm of rural salary (daily

- wage), in $\mathrm{R} \$ /$ day, from 1990 to 2015.

$P B_{t-4}=$ natural logarithm of the real price of live - cattle in the state of Pará, four-year lag, in R $\$$ / arroba, from 1990 to 2015.

$C R_{t-4}=$ natural logarithm of the real value of - rural credit applications in cattle breeding in the state of Pará, four-year lag in R\$, from 1990 to 2015.

$P B Z_{t}=$ natural logarithm of calf's real price, - from 1990 to 2015.

$V D_{l t}=$ dummy variable included in the model to - capture the effect of the creation of Agriculture and Livestock Defense Agency of the State of Pará (ADEPARÁ), which assumes the value 0 in the period 1990-2002, and value 1 in the period 2003-2015.

$T D M_{t-2}=$ rate of deforestation, in percentage, - between 1990 and 2015.

$T=$ trend variable, included in the model to

- capture the technological advancement in beef cattle breeding from 1990 to 2015.

$E B O V_{t}=$ natural logarithm of the bovine herds - in the state of Pará from 1990 to 2015, used as an instrumental variable.

$P F_{t}=$ natural logarithm of the real price of - chicken meat from 1990 to 2015, used as an instrumental variable.

$P S_{t}=$ natural logarithm of the real price of pork

- from 1990 to 2015, used as an instrumental variable.

$P L_{t}=$ natural logarithm of the real price received

- by the producers of bovine milk in the state of Pará, in R \$/liter, from 1990 to 2015, used as an instrumental variable.

Terms of random error: 
$e_{1 t}$ and $e_{2 t}=$ random errors associated with - supply and demand equations, respectively.

Hypotheses to be tested:

According to economic theory, the expected signals for the coefficients of variables are as follows: $a_{1}, a_{3}, a_{5}, a_{6}, a_{7}, b_{2}$, and $b_{3}>0 ; a_{2}, a_{4}$, and $b_{1}<0$

The supply equation can be estimated independently; however, the condition of market equilibrium composes a recursive system with the demand equation. The generalized method of moments (GMM) was used to estimate the parameters of the structural equations of the system, as it involves the main methods of generalized estimation of parameters of linear and nonlinear econometric models and overcomes the problems of violation of the classic autocorrelation hypotheses and heteroscedasticity (GREENE, 2003). In the Amazon, the method has already been applied in the market analysis of several agricultural products such as cowpea, tropical fruits, wood and açaí (SANTANA; SANTOS, 2000; FALESI et al., 2010; SANTANA et al., 2011; NOGUEIRA et al., 2013). Estimates for the cattle market in the state of Pará were obtained using the Eviews software, version 9.5 .

\section{Results and Discussion}

The system of equations of supply and demand of cattle in the state of Pará was correctly specified, as the Hansen $\mathrm{J}$ statistic assumed a value close to zero. The exogenous and instrumental variables explained the variations in the quantities offered and demanded, at $88.95 \%$ and $92.83 \%$, respectively, and the error terms did not show autocorrelation problems, as measured by the Durbin-Watson test (DURBIN; WATSON, 1951) (Table 1).

The results of the supply equation are theoretically consistent and significant at $1 \%$ probability. The variable of live cattle price is the basic reference in the decision-making of cattle ranchers on adoption of technologies and investments, and the supply of animals for slaughter depends on the prices received, with some discrepancy due to the characteristics of production systems (GOODWIN, 1994). The price elasticity coefficient of supply expresses the effect of prices received by cattle ranchers on the supply of slaughter-ready cattle. The coefficient was 0.5652 ; therefore, for each $10 \%$ increase in price with a four-year lag, the supply of animals for slaughter increases by $5.652 \%$ ceteris paribus, indicating that supply is inelastic to price. This temporal lag to price stimulus results from the biological and reproductive characteristics of the animals and the technological level of production systems, with animals fed exclusively on pastures. Thus, between stimulation of prices, investment decision, and adoption of management practices in the production and commercialization of animals ready for slaughter within fridges and slaughterhouses, the livestock cycle lasts for at least four years (BRAGANÇA; BUENO, 2010).

Table 1. Results of the adjustment of supply and demand 
equations of beef cattle in the state of Pará, 1990-2015.

\begin{tabular}{|c|c|c|c|}
\hline Variable & Coefficient & Standard error & T-test \\
\hline \multicolumn{4}{|c|}{ Supply Equation } \\
\hline Intercept & $9.5667 *$ & 1.2655 & 7.5594 \\
\hline$P B_{t-4}$ & $0.5652^{*}$ & 0.0910 & 6.2078 \\
\hline$S R_{t}$ & $-1.5983^{*}$ & 0.1741 & -9.1819 \\
\hline$C R_{t-4}$ & $0.3222 *$ & 0.0580 & 5.5572 \\
\hline$P B Z_{t}$ & $-0.3168 * *$ & 0.0934 & -3.3899 \\
\hline$T D_{t-2}$ & $0.1434^{*}$ & 0.0277 & 5.1701 \\
\hline$V D_{1 t}$ & $0.1220^{*}$ & 0.0307 & 3.9748 \\
\hline Trend $(T)$ & $0.1115^{*}$ & 0.0065 & 17.2103 \\
\hline $\mathrm{R}^{2}$ & 0.8895 & & \\
\hline Adjusted $\mathrm{R}^{2}$ & 0.8343 & & \\
\hline Durbin-Watson - $d$ & 1.2541 & & \\
\hline \multicolumn{4}{|c|}{ Demand Equation } \\
\hline Intercept & $-5.7572 *$ & 1.2371 & -4.6536 \\
\hline$P B_{t}$ & $-0.4020^{*}$ & 0.1059 & -3.7976 \\
\hline$R_{t}$ & $2.1144 *$ & 0.1123 & 18.8203 \\
\hline$V D_{2 t}$ & $0.6431 *$ & 0.0248 & 25.9469 \\
\hline $\mathrm{R}^{2}$ & 0.9283 & & \\
\hline Adjusted $\mathrm{R}^{2}$ & 0.9185 & & \\
\hline Durbin-Watson - $d$ & 0.9447 & & \\
\hline
\end{tabular}

Source: Research Data.

Notes: Statistics $J=0.264 ;(*)$ indicates significance at $1 \%$ probability.

The coefficient of price elasticity of supply obtained differs from the results of previous studies on beef cattle in the state of Pará. Santana (1998) estimated a price elasticity coefficient of the live supply of cattle at -0.78 for the period 1980 1996. Activity was very extensive at that time, characterized by low production cost, higher ages of slaughter, and cattle ranchers with low levels of information. Therefore, even with falling prices due to the livestock cycle, the sale of matrices expanded the supply of animals for slaughter. In another study, covering 1980 to 2000, Santana (2002) estimated the coefficient of price elasticity of supply at -0.06 , but did not present its statistical significance. The results of this study, compared to those obtained in prior studies mentioned, indicates that the price elasticity of supply evolved, mainly due to changes in technology, productivity, and market information search by cattle farmers (SANTOS et al., 2017).

There is an inverse relationship between rural wages and the supply of cattle because it is an important factor in the implementation of management practices of production systems in rural properties. This has become increasingly scarce due to migration and structural changes in rural areas with the young searching for formal jobs in other sectors of the economy (DIEESE, 2014). The coefficient of elasticity cost, which evaluates the effect of rural wage variations on cattle, was -1.5983 , showing that for each $1 \%$ increase in the value of a rural worker's salary, supply tends to decrease around $1.6 \%$. Although breeding beef cattle is not labor intensive, this result reflects the general 
scarcity of this production factor in rural Pará. For example, in 1985, each agricultural establishment had an average of 5 employees, in 1996 it fell to 4.3, and in 2006 it decreased to 3.6 (IBGE, 2016a). This trend has been maintained in recent years due to urbanization, technological changes in agriculture and livestock, precarious working conditions, and access to public services in rural areas (DIEESE, 2014).

From 1990 to 2015, the main instrument to support investments in bovine farming was rural credit. The creation of the Constitutional Financing Fund for the North (FNO), which began operations at the end of 1989, guaranteed a more stable supply of funds for financing agricultural activities throughout the North Region, and particularly in the state of Pará. Therefore, there was a significant increase in the total volume of funds invested. In the analyzed period, the value of rural credit operations grew at a rate of $8.7 \%$ per year, totaling $\mathrm{R} \$ 24.1$ billion. Of this, $\mathrm{R} \$ 13.1$ billion was allocated to beef cattle projects, which represented $54.1 \%$ of the total (BACEN, 2016).

To assess the impact of rural credit on the supply of cattle, we included in the econometric model the value of credit applications in bovine farming projects with a four-period lag, considering the time required for investments to result in production. The elasticity-credit coefficient was 0.3222 , indicating that each increase of $10 \%$ in rural credit supply for bovine farming projects implies a $3.22 \%$ increase in the supply of animals for slaughter four years later. This indicates that resources mainly finance the acquisition of animals for herd composition, reproduction, and property infrastructure, to the detriment of adopting innovations of greater impact, such as recovery and improvement of pastures, artificial insemination and embryo transfer, which would bring greater precocity and productivity benefits to production systems (ARIMA et al., 2005; SANTOS et al., 2012).

Calf price is an important variable in production costs and is the benchmark of the replacement market (SOUSA, 2005; SACHS; MARTINS, 2007). In the early $1990 \mathrm{~s}$, with 4.6 arrobas of live cattle, it was possible to acquire a calf. In 2015, this ratio was 7.6 arrobas for a calf, a depreciation of $65.22 \%$ in the exchange ratio, with costs implications, mainly for cattle ranchers who work with rearing and fattening. Consequently, the cross-elasticity coefficient between the supply of cattle for slaughter and calf price was -0.3168 . Thus, for each $10 \%$ increase in the price of the calf, the supply of cattle tends to decrease $3.168 \%$ ceteris paribus.

The rate of deforestation had a direct and significant relationship with the supply of cattle. The cross-elasticity coefficient, equal to 0.1434 , indicates that each $10 \%$ increase in deforestation with a two-year lag implies a $1.434 \%$ increase in the supply of cattle in the present time. As supply is less inelastic than demand, deforestation tends to benefit fridges more than cattle ranchers.

The trend variable, included to capture the technological advancement in beef cattle breeding in Pará, was positive and statistically significant. During this period, there was a large increase in official slaughtering, from approximately 500 thousand heads in 1990 to 2.7 million in 2015, which corresponds to a growth rate of $8.1 \%$ per year. Productivity gains were also observed in the period under analysis, since at the beginning of the 1990s, the average slaughter yield was 15.37 arrobas for oxen and 12.15 arrobas for cows, and at present, it is 18.4 arrobas for oxen and 13.5 arrobas for cows (IBGE, 2016c).

In the demand equation, all coefficients are significant at $1 \%$ probability. The demand for cattle by fridges and slaughterhouses is inelastic to price, as for each $10 \%$ increase in livestock prices there is a reduction of $4.02 \%$ ceteris paribus. Regarding per capita income, the coefficient of 1.4769 reveals that the demand for cattle by the slaughterhouses responds positively to increases in consumer income, a result consistent with consumer 
theory. That this coefficient is higher than 1 can be justified as the real income increases, the demands on the origin and quality of the meat also increase primarily through consumption of meat produced in establishments under federal inspection. Note that at the end of the 1990s, SIF slaughterhouses accounted for $50.6 \%$ of all slaughtered animals. In the last three years (2013-2015), this participation reached $73.5 \%$ (IBGE, 2016c).

The dummy variable was included in the supply and demand equations to capture the effect of the creation of the ADEPARÁ in 2002, through Law No. 6.842 (PARÁ, 2016). Regarding animal production, its main function is to implement national animal health policies with emphasis on the National Program for the Eradication and Prevention of Foot-and-Mouth Disease (PNEFA) and the National Program for the Control and Eradication of Animal Brucellosis and Tuberculosis (PNCEBT), in accordance with the guidelines of the World Organization for Animal Health (OIE). The dummy variable showed a positive and significant coefficient at $1 \%$ of probability, indicating an important institutional advance in the development of cattle breeding in Pará, as it created a favorable environment for both cattle ranchers and agribusiness investments, aiming to participate in a broad market, especially for meat exports.

During this period, progress was achieved against foot-and-mouth disease, with effects on beef cattle breeding and dairy farming. Currently, based on the results of vaccination in the second half of 2015, 21.3 million bovine and buffalo heads were vaccinated, which indicates vaccination coverage of higher than 98.9\% (MAPA, 2016b). The advances in vaccination coverage since the creation of ADEPARÁ resulted in the recognition of Southeastern Pará as free of foot-and-mouth disease with vaccination in 2007 , followed by the municipalities of the Northern region of Pará in 2014 (MARQUES et al., 2015; MAPA, 2016c). This led to the expansion and modernization of the state's cold storage facility. In 2002, there were 48 establishments under inspection (federal, state, and municipal), which slaughtered a total of 1.3 million head of cattle. In 2015, this number was 2.7 million, involving 55 establishments, of which 14 are under federal inspection, exporting meat to the rest of Brazil and the international market.

\section{Conclusions}

The demand for beef cattle is inelastic in the state of Pará, because for each increase of $10 \%$ in price, the quantities demanded tend to decrease $6.048 \%$ ceteris paribus. The increase in the per capita income of consumers has a positive effect on demand, especially of fridges under federal inspection.

Supply is inelastic to prices and rural credit applications, responding with a lag of four years to the stimuli of these variables, depending on the biological and technological characteristics of the production systems. The scarcity of labor in rural Pará affects the supply of cattle, as each increase of $1 \%$ in the wages of rural workers implies a $1.6 \%$ reduction in supply. The increases in the price of calves also have a negative impact, as there was a marked depreciation in the exchange ratio between calf and ox in the analyzed period. We also observed that deforestation increases the supply of cattle and that the slaughterhouses own the majority of the economic surplus generated by beef cattle breeding.

There were productivity gains in the analyzed period, evidenced by the higher carcass yield of slaughtered cattle, which went from 15.37 arrobas of oxen and 12.15 arrobas of cows in the early 1990 s to 18.4 and 13.5 arrobas, respectively, in 2015. The public health animal protection policies implemented since the creation of the Agriculture and Livestock Defense Agency of the state of Pará have increased the supply of cattle and expanded the agribusiness structure of slaughtering, contributing to the supply of quality meat to largest international markets. 


\section{References}

ALMEIDA, C. A.; COUTINHO, A. C.; ESQUERDO, J. C. D. M.; ADAMI, M.; VENTURIERI, A.; DINIZ, C. G.; DESSAY, N.; DURIEUX, L.; GOMES, A. R. High spatial resolution land use and land cover mapping of the Brazilian Legal Amazon in 2008 using Landsat-5/TM and MODIS data. Acta Amazônica, Manaus, v. 46, n. 3, p. 291-302, 2016.

ARIMA, E.; BARRETO, P.; BRITO, M. Pecuária na Amazônia: tendências e implicações para a conservação ambiental. Belém: IMAZON, 2005. 76 p.

BANCO CENTRAL DO BRASIL - BACEN. Anuário estatístico do crédito rural. Brasília: Banco Central do Brasil, 2016. Disponível em: <http://www.bacen.gov. br>. Acesso em: 5 dez. 2016.

BARBOSA, F. A.; SOARES-FILHO, B. S.; MERRY, F. D.; AZEVEDO, H. O.; COSTA, W. L. S.; COE, M. T.; BATISTA, E. L. S.; MACIEL, T. G.; SHEEPERS, L. C.; OLIVEIRA, A. R.; RODRIGUES, H. O. Cenários para a pecuária de corte amazônica. Belo Horizonte: UFMG, 2015. 146 p.

BOECHAT, A. M. F.; ALVES, A. F. A política de defesa da concorrência no setor de abate de bovinos. Revista Econômica do Nordeste, Fortaleza, v. 45, n. 2, p. 112124, 2014.

BRAGANÇA, R. C.; BUENO, N. P. O ciclo pecuário no Brasil: uma análise usando a metodologia da dinâmica de sistemas. Revista de Economia e Agronegócio, Viçosa, MG, v. 8, n. 2, p. 199-220, 2010.

DEPARTAMENTO SINDICAL DE ESTATÍSTICAS E ESTUDOS SOCIOECONÔMICOS - DIEESE. O mercado de trabalho assalariado rural brasileiro. São Paulo: DIEESE, 2014. 33p. (Estudos e Pesquisas, 74).

DURBIN, J.; WATSON, G. S. Testing for serial correlation in Least Squares Regression, II. Biometrika, London, v. 38, n. 1-2, p. 159-178, 1951.

FALESI, L. A.; SANTANA, A. C.; HOMMA, A. K. O.; GOMES, S. C. Dinâmica do mercado de frutas na mesorregião Nordeste Paraense no período de 19852005: produção e preços. Teoria e Evidência Econômica, Passo Fundo, v. 16, n. 35, p. 306-326, 2010.

FUNDAÇÃO GETÚLIO VARGAS - FGV. FGVDADOS: informação econômica on-line. Rio de Janeiro: FGV, 2016. Disponível em: <http://fgvdados.fgv.br>. Acesso em: 5 dez. 2016.

GOODWIN, J. W. Agricultural price analysis and forecasting. New York: John Wiley \& Sons, 1994. 344 p.

GREENE, W. H. Econometrics analysis. $5^{\text {th }}$ ed. New Jersey: Prentice Hall, 2003. 802 p.
HOMMA, A. K. O. A Terceira natureza da Amazônia. Revista Paranaense de Desenvolvimento, Curitiba, v. 38, n. 132, p. 27-42, 2017.

INSTITUTO BRASILEIRO DE GEOGRAFIA E ESTATÍSTICA - IBGE. Censo Agropecuário 2006 -segunda apuração. Rio de Janeiro: IBGE, 2016a. Disponível em: $<$ http://www.sidra.ibge.gov.br $>$. Acesso em: 5 dez. 2016.

- Pesquisa pecuária municipal. Rio de Janeiro: IBGE, 2016b. Disponível em: <http://www.sidra.ibge. gov.br>. Acesso em: 5 dez. 2016.

Pesquisa trimestral de abates de animais. Rio de Janeiro: IBGE, 2016c. Disponível em: <http://www. sidra.ibge.gov.br>. Acesso em: 5 dez. 2016.

INSTITUTO DE PESQUISAECONÔMICAAPLICADA -IPEADATA. Base de dados: macroeconômico. Brasília: IPEA, 2016. Disponível em: <http://www.ipeadata.gov. br>. Acesso em: 5 dez. 2016.

INSTITUTO NACIONAL DE PESQUISAS ESPACIAIS - INPE. Levantamento de informações de uso e cobertura da terra na Amazônia - Terraclass. Brasília: INPEEMBRAPA, 2016a. Disponível em: <http://www.inpe. $\mathrm{br} / \mathrm{cra} /$ projetos_pesquisas/dados_terraclass.php $>$. Acesso em: 5 dez. 2016.

Projeto PRODES: monitoramento da floresta Amazônica Brasileira por satélite. Brasília: INPE, 2016b. Disponível em: $<$ http://www.obt.inpe.br/prodes/index. php>. Acesso em: 5 dez. 2016.

MARQUES, G. H. F.; STEFANO, E. de; RIBEIRO, C. P.; TURISSI, L. H. A.; DIAS, R. A.; NARANJO, J.; POZZETTI, P. S.; COSTA, J. F.; PITUCO, E. M. A experiência brasileira na erradicação da febre aftosa e o emprego do sistema I-ELISA 3ABC/EITB para certificação sanitária de bovinos e bubalinos. Arquivos do Instituto Biológico, São Paulo, v. 82, n. 1, p. 1-11, 2015.

MINISTÉRIO DA AGRICULTURA, PECUÁRIA E ABASTECIMENTO - MAPA. Campanhas de vacinação contra febre aftosa. Brasília: MAPA, 2016b. Disponível em: <http://www.agricultura.gov.br/ febreaftosa $>$. Acesso em: 5 dez. 2016.

. Evolução geográfica do processo de implantação de zona livre de febre aftosa no Brasil. Brasília: MAPA, 2016c. Disponível em: <http://www.agricultura.gov.br/ febreaftosa $>$. Acesso em: 5 dez. 2016.

Valor bruto da produção agropecuária (VBP). Brasília: MAPA, 2016a. Disponível em: <http://www. agricultura.gov.br/ministerio/gestao-estrategica/valorbruto-da-producao>. Acesso em: 5 dez. 2016. 
MOITA, R. M.; GOLANI, L. A. Oligopsônio dos frigoríficos: uma análise empírica de poder de mercado. Revista de Administração Contemporânea, Rio de Janeiro, v. 18, n. 6, p. 772-794, 2014.

NOGUEIRA, A. K. M.; SANTANA, A. C.; GARCIA, W. S. A dinâmica do mercado de açaí fruto no Estado do Pará: de 1994 a 2009. Revista Ceres, Viçosa, MG, v. 60, n. 3, p. 324-331, 2013.

NORWOOD, F. B.; LUSK, J. Agricultural marketing and price analysis. New Jersey: Pearson Prentice Hall, 2008. 445p.

PARÁ. Lei no ${ }^{\circ}$. 842, de 17 de setembro de 2002. Dispõe sobre a criação da Agência de Defesa Agropecuária do Estado do Pará (ADEPARÁ) e dá outras providências. Belém: Imprensa Oficial, 2016. Disponível em: $<$ http:// www.pge.pa.gov.br/sites/default/files/lo6482repub_alt. pdf>. Acesso em: 5 dez. 2016.

RIVERO, S.; ALMEIDA, O.; ÁVILA, S.; OLIVEIRA, W. Pecuária e desmatamento: uma análise das principais causas diretas do desmatamento na Amazônia. Nova Economia, Belo Horizonte, v. 19, n. 1, p. 41-66, 2009.

SACHS, R. C. C.; MARTINS, S. S. Análise do comportamento dos preços do boi gordo e do bezerro na pecuária de corte paulista, janeiro de 1995 a abril de 2006: uma aplicação do modelo VAR. Revista de Economia Agrícola, São Paulo, v. 54, n. 1, p. 75-85, 2007.

SANTANA, A. C. Cadeia produtiva de gado de corte: análise de mercado e avaliação de políticas. Belém: Imprensa Oficial do Estado do Pará, 1998. 119 p.

. Fatores sustentáveis do desenvolvimento das cadeias produtivas de base agrária na Amazônia. Ver-aCiência, Belém, v. 1, n. 1, p. 18-23, 2012.

O fundo constitucional de financiamento do Norte e o desenvolvimento da Amazônia. Belém: $\mathrm{M} \& \mathrm{~S}$ Editora, 2002. 623 p.
SANTANA, A. C.; SANTANA, A. L.; SANTOS, M. A. $\mathrm{S}$. Influência do desmatamento no mercado de madeira em tora da região Mamuru-Arapiuns, Sudoeste do Pará. Revista de Ciências Agrárias, Belém, v. 54, n. 1, p. 4453, 2011.

SANTANA, A. C.; SANTOS, M. A. S. O mercado de caupi no estado do Pará: aplicação do método dos momentos generalizados. Revista de Ciências Agrárias, Belém, v. 34, n. 1, p. 47-58, 2000.

SANTOS, M. A. S.; LOURENÇO JUNIOR, J. B.; SANTANA, A. C.; HOMMA, A. K. O.; ANDRADE, S. J. T.; SILVA, A. G. M. Caracterização do nível tecnológico da pecuária bovina na Amazônia Brasileira. Revista de Ciências Agrárias, Belém, v. 60, n. 1, p. 103-111, 2017.

SANTOS, M. A. S.; REBELLO, F. K.; SANTANA, A. C. A política de crédito rural no estado do Pará: distribuição espacial e concentração das aplicações no período 2000-2010. Revista em Agronegócio e Meio Ambiente, Maringá, v. 5, n. 3, p. 493-508, 2012.

SANTOS, M. A. S.; SANTOS, J. S. B.; CUNHA, S. J. T.; SANTANA, A. C. Mercado e dinâmica local da cadeia produtiva da pecuária de corte na Região Norte. Belém: Banco da Amazônia, 2007. 48 p. (Estudos Setoriais, 1).

SECRETARIADEESTADODEDESENVOLVIMENTO AGROPECUÁRIO E DA PESCA DO ESTADO DO PARÁ - SEDAP. Dados agropecuários. Cidade: Editora, 2016. Disponível em: <http://www.sedap.pa. gov.br/ pecuaria.php>. Acesso em: 5 dez. 2016.

SOUSA, C. C. Evolução e sazonalidade dos preços e da relação de troca do boi gordo e do bezerro no estado de São Paulo. Informações Econômicas, São Paulo, v. 35, n. 10, p. 32-41, 2005. 